\title{
CERN jumps another hurdle towards proton accelerator
}

\begin{abstract}
Munich. Carlo Rubbia, director general of the European particle physics laboratory in Geneva (CERN), has confirmed that he will be ready by December with a detailed budget for the proposed next-generation particle accelerator, the Large Hadron Collider (LHC). The news will be a relief to the many who feared that technical difficulties in the development of the ultra-high performance superconducting magnets would delay the project.
\end{abstract}

Rubbia told last Friday's meeting of the CERN council that the magnets being developed under CERN contracts in seven different member countries would, in the next few months, be shown to be capable of achieving the required magnetic field of 9 Tesla. CERN hopes to use the LHC to search for high energy particles - the top quark, the Higgs particle (or 'God particle') — and supersymmetrical particles, which are predicted to exist, but which have not so far been detected.

But fixing a budget is, of course, only the very start of the story. The cost of the accelerator is estimated to be around US\$3 billion, and CERN's 17 member states will need to be convinced that the return will be worthwhile before they agree (as they must unanimously) to underwrite such a largescale project. US congressmen were not convinced that a similar, but much more expensive proton collider (the Superconducting Super Collider or SSC), to be built in Texas, could be justified by its esoteric research aims. They voted last Thursday against financial support (see right).

The LHC, if it gets the go-ahead, could become even more international than now planned if the SSC is abandoned. CERN has an open-door policy to scientists in nonmember countries; this year 500 of its 6,000 visiting scientists were American. "You can't marry a wife until the husband is dead", says a CERN spokesman, "but CERN could benefit from a more collaborative effort if only one proton collider is built."

The CERN council meeting also confirmed the election of Hubert Curien as CERN president in 1994. Curien was professor of physics at the University of Paris and l'Ecole Normale Superieure before working for two spells as research minister in the French governments in 1984-86 and 1988-93. He takes over from Sir William Mitchell for an initial period of one year.

Christopher Llewellyn Smith, professor of theoretical physics at the University of Oxford, takes over from Carlo Rubbia as director general for a five-year stint at the beginning of next year. He is a firm supporter of the LHC programme.

Alison Abbott

\section{SSC falls victim to congressional austerity}

Washington. The Superconducting Super Collider (SSC) was probably mortally wounded this week, when a proposal to pay $\$ 620$ million towards the Texas accelerator in the coming year was defeated in the US House of Representatives. Supporters of the \$9-billion project in Congress and the highenergy physics community fear that, even if the Senate supports the SSC (as is probable), last Thursday's 280 to 141 majority will make it impossible to rescue the project when representatives of both houses of Congress meet to decide the matter finally.

The SSC vote was only one manifestation of the wider mood in Washington during a week that saw big science take a hammering from congressmen acting tough to cut budget spending:

On Tuesday, authorization of President Bill Clinton's revised \$10.5-billion space station plan scraped through the House by one solitary vote.

- Two days later, as the SSC fell, the House voted 272 to 162 to cut to zero the funds requested for the Integrated Fast Reactor (IFR) at the Argonne West laboratory in Idaho. The proposal before the House already reduced the IFR's budget from $\$ 125$ million to $\$ 32$ million (see Nature 362,383 ; 1993).

- By a majority of 329 to 91 , the House removed a $\$ 25$ million request to continue development of the SP-100, a small spacebased nuclear reactor left over from the Star Wars programme.

Supporters of the SSC complain that there was little they could do, in the prevailing atmosphere, to get their arguments heard. "They want to be able to go home and say "we've cut something'", one official said.

According to congressional staff, the collider has suffered because many in Congress see their choice as being between the SSC and the Space Station. The latter is said to support 75,000 jobs, many of them in the battered aerospace industries of Texas and California. SSC is thus easier to cut, although cancellation will mean $\$ 1.5$ billion wasted and a spectacular white elephant near Dallas.

Leading high-energy physicists who have fought for the SSC for almost a decade are almost ready to throw in the towel. "It seems to me that we have lost," concedes Stan Wojcicki of Stanford University, California, chairman of the Department of Energy's High Energy Physics Advisory Panel (HEPAP). "I worry about what it says about our nation, and its ability to carry things through", Wojcicki says.

He concedes, though, that scientists will have themselves to blame if the project falls. "A lot of us don't talk enough about what we are doing, so the public and its representatives are not aware of it." Wojcicki, now on sabbatical at the SSC laboratory near Dallas, says that, despite his own pessimism, most physicists are continuing on the basis that the SSC will be built. "You can't base your actions on just one vote," he says.

Supporters of the collider have also attacked enemies in Congress for stretching out the programme, thus increasing its cost and scaring off international collaborators - and then attacking it for having higher costs and no collaborators.

In a similar vein, in the wake of the Space Station's narrow victory, George Brown (Democrat, California), who is chairman of the House Science, Space and Technology Committee, chastised his opponents for "delaying, obstructing, and driving up costs on this project". Brown - doubtless to no avail - asks Space Station opponents to hold fire on a programme that, "has been debated, amended and redesigned nearly to death."

The SSC debate will now rest until late August when the Senate, which last year supported it by 66 to 34, will probably back it by a narrower margin. The conference between both houses - which saved the programme last year, in more auspicious circumstances - will then decide its fate.

The Space Station faces another hurdle this week with a second House vote on appropriation of funds for next year. With strong Senate and White House support and NASA engaged on finalizing the president's preferred design option, its prospects look more secure than they have done all year.

But a planned visit to Washington by Russian prime minister Viktor Chernomyrdin to discuss fuller Russian participation has been postponed, because of US concerns about Russia's supply of missiles to India.

In Idaho, the fast breeder reactor could yet survive the House vote against it. The Argonne West facility has strong backing in the Senate, which may even support full development funds as opposed to the 80 per cent cutback in the president's budget. A compromise might then follow.

But the space reactor, not included in the president's budget but added later by a House appropriations subcommittee, is well and truly dead after last Thursday's vote. Taken as a whole, these votes reflect more than just a fashion for deficit-reduction. They may prove instead to be an early indicator of how vulnerable US science funding has become without Cold War arguments to protect it. If that is the case, researchers engaged on projects that are not 54 miles incircumference may soon feel the consequences. 